\title{
MgO Fertilizer Sole and Combined with Organic and Inorganic Fertilizers: Effect on Soil Chemical Properties, Turmeric Performance, and Quality in a Tropical Alfisol
}

\author{
Aruna Olasekan Adekiya $(\mathbb{D}$, Elizabeth Temitope Alori, \\ Christopher Muyiwa Aboyeji $(\mathbb{D}$, Oluwagbenga Dunsin, Kehinde Abodunde Adegbite, \\ Charity O. Aremu, Olasunkanmi Bamiro, Wutem Sunny Ejue, Faith Oluwatobi Okunlola, \\ and Omowumi Oluwanifemi Adesola
}

College of Agricultural Sciences, Landmark University, P. M. B. 1001, Omu-Aran, Kwara State, Nigeria

Correspondence should be addressed to Aruna Olasekan Adekiya; adekiya2009@yahoo.com

Received 11 May 2019; Accepted 8 June 2019; Published 20 June 2019

Academic Editor: Sanjay Govindwar

Copyright (C 2019 Aruna Olasekan Adekiya et al. This is an open access article distributed under the Creative Commons Attribution License, which permits unrestricted use, distribution, and reproduction in any medium, provided the original work is properly cited.

For soil fertility maintenance, secondary nutrient such as Magnesium $(\mathrm{Mg})$ is always being neglected. However, its role is critical in the growth, yield, and quality of crops. Therefore, two field experiments were initiated in 2017 and 2018 to evaluate the response of soil chemical properties, performance, and qualities of turmeric (Curcuma longa L.) to Mg fertilizer alone and in combination with poultry manure (PM) and NPK 15-15-15 fertilizer (NPK). The treatments applied were the following: (i) PM alone at $8 \mathrm{t} \mathrm{ha}{ }^{-1}$, (ii) NPK alone at $200 \mathrm{~kg} \mathrm{ha}^{-1}$, (iii) $\mathrm{Mg}$ fertilizer alone (in form of $\mathrm{MgO}$ ) at $20 \mathrm{~kg} \mathrm{ha}^{-1}$, (iv) $\mathrm{PM}$ at $8 \mathrm{t} \mathrm{ha}^{-1} \mathrm{with} \mathrm{MgO}$ at $20 \mathrm{~kg}$ $\mathrm{ha}^{-1}\left(\mathrm{PM}+\mathrm{Mg}\right.$ ), (v) NPK at $200 \mathrm{~kg} \mathrm{ha}^{-1}$ with MgO at $20 \mathrm{kgha}^{-1}$ (NPK $+\mathrm{Mg}$ ), and (vi) control (no amendment of any kind). $\mathrm{PM}, \mathrm{NPK}$, and $\mathrm{Mg}$ fertilizers alone or NPK $+\mathrm{Mg}$ and PM + Mg increased soil chemical properties, performance (plant height, number of leaves, number of tillers, number of rhizomes, and fresh rhizome weight), and minerals and vitamins $\mathrm{C}$ and $\mathrm{A}$ contents of turmeric rhizome compared with the control. By averaging 2017 and 2018, Mg fertilizer alone increased the yield of turmeric by $10.8 \%$ compared with the control. For this experiment, NPK + Mg increased growth and yield of turmeric compared with other treatments. Also, averaging 2017 and 2018, NPK + Mg increased rhizome yield of turmeric by $13.6 \%$ and $10.6 \%$ compared with PM $+\mathrm{Mg}$ and NPK alone, respectively. Similarly, PM + Mg significantly improved mineral and vitamins contents compared with other treatments. Therefore, for those that desire turmeric rhizome for its nutritive value, $\mathrm{PM}+\mathrm{Mg}$ is recommended. For those that want quantity, NPK $+\mathrm{Mg}$ is recommended.

\section{Introduction}

Turmeric (Curcuma longa L.) is a spice crop that belongs to the family Zingiberaceae. There have been increases in the demand for turmeric over the last decade because of its medicinal values. Turmeric rhizomes are endowed with a yellowish compound known as curcumin and volatile oils which are of great medicinal value to mankind. Turmeric is rich in minerals ( $\mathrm{Fe}, \mathrm{Ca}, \mathrm{Mg}$, and $\mathrm{P}$ ) and vitamin $\mathrm{A}$ [1]. Various supplements and drinks have also been reported to be produced from turmeric.

Turmeric is a crop that can exhaust soil fertility quickly. Therefore, due to its long gestation period (about 8 months) and high productivity it requires high fertilizer input [2]. In the tropics, to maintain productivity for a viable crop production maintenance of soil fertility with addition of fertilizers is inevitable.

Maintaining soil fertility has been based on adding different manures and macronutrients from chemical fertilizers [3]. N, P, and K either individually or in combination are considered to be the main nutrient elements to be responsible for the performance and quality of crops [4]. Secondary nutrients such as Magnesium (Mg) had always been neglected. However, its singular role in the growth, yield, and quality of crops is germane [4]. Addition of secondary nutrients such as $\mathrm{Mg}$ with either organic or inorganic fertilizer would complement 
their uses and improve soil chemical properties and crop yield.

$\mathrm{Mg}$ is involved in many physiological and biochemical processes in plants. It functions as the central atom of the chlorophyll molecule in the light absorbing complex of chloroplasts and its contribution to photosynthetic fixation of $\mathrm{CO}_{2}[5,6]$. It is required to activate a number of enzymatic systems in plant tissues such as carbohydrate metabolism, the citric acid cycle in cell respiration, and oil synthesis. It also performs structural roles in plants linking together the subunits of ribosomes [7]. For improved human nutrition and food quality, $\mathrm{Mg}$ addition to daily food intake is now becoming an important issue globally [8].

Turmeric has been reported to respond well to NPK 15-1515 fertilizer [9] and poultry manure (PM) [10]. For example, an experiment with four turmeric varieties with organic and inorganic fertilizers [11] reported higher yields at $4884 \mathrm{kgha}^{-1}$ from farmyard manure (organic) compared with $4623 \mathrm{kgha}^{-1}$ recorded with NPK fertilizer (inorganic) manure. Rhizome yield of turmeric was also reported to increase with increasing concentration of $\mathrm{MgSO}_{4}$ applied as foliar a spray [12]. Crops react in different ways to different chemical or organic fertilizers. Therefore appropriate fertilizer combinations could influence soil chemical properties, crop yield, and quality.

Response of sole $\mathrm{Mg}$ fertilizer in combination with organic and inorganic fertilizer to crops especially turmeric is scarce in the literature. Therefore, this study was to determine the effect of $\mathrm{Mg}$ fertilizer alone and in combination with organic (PM) and inorganic (NPK 15-15-15) fertilizers on soil chemical properties, growth, rhizome yield, and quality. In this experiment, we hypothesized that soil chemical properties and turmeric growth and yield will react differently to sole NPK fertilizer, PM, Mg fertilizer, and the combinations of Mg fertilizer with either NPK fertilizer or PM. Experiments were conducted to validate these working hypotheses to determine which combinations of $\mathrm{Mg}$ fertilizer would have the greatest effect.

\section{Materials and Methods}

2.1. Site Description and Treatment. The studies were carried out at Owo, Ondo State, Nigeria, in 2017 and 2018. Owo, Nigeria, receives a total mean annual rainfall of about $1300 \mathrm{~mm}$ and mean air temperature of about $32^{\circ} \mathrm{C}$. The site is located at latitude $5^{\circ} 12^{\prime} \mathrm{N}$ and longitude $5^{\circ} 35^{\prime} \mathrm{E}$. The area has a diurnal rainfall, with first season starting in March to July with a short dry spell in August known as "August break," followed by the second rainy season between September and November. The soil at Owo is an Alfisol or Luvisol. The site used for the experiment was just recovered from one year after a continuous cropping to yam (Dioscorea rotundata) and maize (Zea mays) for two years.

The treatments in 2017 and 2018 were the following: (i) application of PM alone at the rate of $8 \mathrm{t} \mathrm{ha}^{-1}$ based on field recommendation for turmeric production [10]; (ii) application of NPK 15-15-15 fertilizer alone at the rate of $200 \mathrm{~kg} \mathrm{ha}^{-1}$ based on field recommendation for turmeric production [9]; (iii) application of $\mathrm{Mg}$ fertilizer alone (in form of $\mathrm{MgO}$ ) at the rate of $20 \mathrm{~kg} \mathrm{ha}^{-1}$; (iv) application of PM at $8 \mathrm{tha}^{-1}$ with $\mathrm{MgO}$ at $20 \mathrm{~kg} \mathrm{ha}^{-1}$; (v) application of NPK fertilizer at $200 \mathrm{~kg} \mathrm{ha}^{-1}$ with $\mathrm{MgO}$ at $20 \mathrm{kgha}^{-1}$; (vi) control (no amendment of any kind). The experimental design used was RCBD with three replications. Plots were $2.5 \times 2.5 \mathrm{~m}$ with $0.5 \mathrm{~m}$ apart and $1 \mathrm{~m}$ space between blocks. The same site, layout, and treatments used in 2017 were repeated in 2018.

2.2. Incorporation of PM, Crop Establishment, and Applications of NPK 15-15-15 and MgO Fertilizers. The PM was composted two weeks to mineralize before application. Ploughing and harrowing (land preparation) were done in April in each year 2017 and 2018. The PM was applied to the required plots at three weeks prior to planting of turmeric rhizomes. At planting turmeric rhizomes were cut to about $50 \mathrm{~g}$ and treated with a fungicide (Benlate) to wade against seed and soil-borne pathogens before planting rhizomes using a hand trowel to a depth of about $6 \mathrm{~cm}$ at a spacing of $30 \mathrm{~cm} \times 30 \mathrm{~cm}$ to give a plant population of 111,111 plants $\mathrm{ha}^{-1}$. NPK 15-15-15 fertilizer and $\mathrm{MgO}$ fertilizers were applied to the required plots 4 weeks after planting and after the first weeding. The fertilizers were applied $10 \mathrm{~cm}$ away from the turmeric plant by ring method. Weeding was subsequently done every month to keep the plots clean.

2.3. Turmeric Performance. Ten randomly selected turmeric plants were used for the determination of growth parameter (plant height, number of leaves, and tillers) after 150 days of turmeric growth when the turmeric would have developed full canopy formation. Plant height was taken by measuring from the ground level to the tallest leaf apex using a ruler. The numbers of leaves were counted. At harvesting ( 8 months after planting), individual plants were uprooted using hoe. The numbers of rhizomes were counted and the fresh rhizome weights of turmeric were recorded using a top loading balance.

2.4. Determination of Soil Properties. Before experimentation in 2017, soil samples $(0-15 \mathrm{~cm})$ were collected from 10 randomly selected locations within the experimental site and mixed together to represent a composite soil sample. The soil sample was later air-dried sieved using a $2 \mathrm{~mm}$ sieve and analyzed for particle size, organic $\mathrm{C}, \mathrm{pH}$, total $\mathrm{N}$, available $\mathrm{P}$, exchangeable $\mathrm{K}, \mathrm{Ca}, \mathrm{Mg}$, and $\mathrm{pH}$ (water). At the end of each year, soil samples were also collected on each experimental plot and the chemical properties were analyzed. Particle size analysis was determined using the hydrometer method [13]. Soil organic carbon was determined by the procedure of Walkley and Black using the dichromate wet oxidation method [14]. Organic matter was calculated by multiplying $\mathrm{C}$ by 1.724 . Total $\mathrm{N}$ was determined by the micro-Kjeldahl digestion method [15]. Available P was determined by Bray1 extraction followed by molybdenum blue colorimetry [16]. Exchangeable $\mathrm{K}, \mathrm{Ca}$, and $\mathrm{Mg}$ were extracted using $1 \mathrm{M}$ ammonium acetate. Thereafter $\mathrm{K}$ level was determined on a flame photometer, and $\mathrm{Ca}$ and $\mathrm{Mg}$ were determined by EDTA titration [17]. Soil pH was determined using a soilwater medium at a ratio of 1:2 with a digital electronic $\mathrm{pH}$ meter. 
TABLE 1: Initial soil characteristics before experimentation.

\begin{tabular}{lc}
\hline Property & Value \\
\hline Sand (\%) & 68.2 \\
Silt (\%) & 16.3 \\
Clay (\%) & 15.5 \\
Textural class & Sandy loam \\
pH (water) & 5.71 \\
Soil organic matter (\%) & 2.56 \\
Total N (\%) & 0.18 \\
Available P $\left(\mathrm{mg} \mathrm{kg}^{-1}\right)$ & 9.50 \\
Exchangeable K $\left(\mathrm{cmol} \mathrm{kg}^{-1}\right)$ & 0.21 \\
Exchangeable Ca $\left(\mathrm{cmol} \mathrm{kg}^{-1}\right)$ & 1.23 \\
Exchangeable $\mathrm{Mg}\left(\mathrm{cmol} \mathrm{kg}^{-1}\right)$ & 0.31 \\
\hline
\end{tabular}

2.5. Chemical Analysis of PM and Turmeric Rhizome. Turmeric rhizomes each year were harvested and analyzed for minerals ( $\mathrm{Na}, \mathrm{K}, \mathrm{Mg}, \mathrm{Ca}$, and $\mathrm{Fe}$ ) and vitamins $\mathrm{A}$ and $\mathrm{C}$. The minerals in the turmeric rhizome were analyzed using the method described by Association of Official Analytical Chemist [18]. Vitamin A was determined spectrophotometrically by using the hexane method while Vitamin $C$ was extracted from the turmeric with oxalic acid and then titrated using 2, 6-dichlorophenol indophenol [19]. The PM was air dried and sieved and then analyzed for chemical properties ( $\mathrm{pH}$ (water), ash, organic C, N, P, K, Ca, $\mathrm{Mg}, \mathrm{Na}, \mathrm{Cu}, \mathrm{Mn}, \mathrm{S}$, and $\mathrm{Zn}$ ) using the method recommended by [20].

2.6. Statistical Analysis. Data were subjected to analysis of variance (ANOVA) using SPSS 21, and means were separated using Duncan's multiple range test (DMRT) at $\mathrm{p}<0.05$ probability level.

\section{Results}

3.1. Initial Soil Fertility and Chemical Analysis of the Soil Amendments Used for the Experiment. Tables 1 and 2, respectively, show the initial soil physical and chemical properties of the site used before experimentation and the chemical analysis of the PM, NPK, and MgO fertilizers used for the study. The soil was sandy loam, acidic, and low in OM, N, $\mathrm{P}, \mathrm{Ca}$, and $\mathrm{Mg}$ but adequate in $\mathrm{K}$ [21]. The poultry manure has both macro- and microelements. NPK fertilizer has high values of $\mathrm{N}, \mathrm{P}$, and $\mathrm{K}$ while $\mathrm{MgO}$ has high $\mathrm{Mg}$ content compared with other amendments.

3.2. Response of Soil Chemical Properties. Although PM alone and $\mathrm{PM}$ with $\mathrm{Mg}$ fertilizer $(\mathrm{PM}+\mathrm{Mg}$ ) increased $\mathrm{pH}, \mathrm{OM}$, $\mathrm{N}, \mathrm{P}, \mathrm{K}, \mathrm{Ca}$, and $\mathrm{Mg}$ contents of the soil compared with the control, their application only resulted in significant differences $(\mathrm{p}<0.05)$ for $\mathrm{Mg}$ (Table 3). NPK alone and NPK with $\mathrm{Mg}$ fertilizer (NPK $+\mathrm{Mg}$ ) significantly increased $\mathrm{N}, \mathrm{P}, \mathrm{K}$, and $\mathrm{Mg}$ concentrations of the soil compared with the control. Their application however did not significantly increase ( $\mathrm{p}$ $<0.05) \mathrm{pH}, \mathrm{OM}$, and $\mathrm{Ca}$ concentration compared with the control. NPK $+\mathrm{Mg}$ fertilizer increased soil Mg concentration significantly compared with NPK alone. Mg alone significantly increased $\mathrm{N}, \mathrm{P}, \mathrm{K}, \mathrm{Ca}$, and $\mathrm{Mg}$ concentrations of the soil compared with the control whereas the values of $\mathrm{pH}$ and $\mathrm{OM}$ were not significantly different. Compared with other treatments, NPK + Mg significantly $(\mathrm{p}<0.05)$ increased N, P, and $\mathrm{K}$ concentrations of the soil. When compared with other treatments, $\mathrm{PM}+\mathrm{Mg}$ significantly $(\mathrm{p}<0.05)$ increased soil $\mathrm{pH}, \mathrm{OM}, \mathrm{Ca}$, and $\mathrm{Mg}$ concentrations.

3.3. Response of Growth and Yield of Turmeric. Averaged over the two years, all amendments increased plant height, number of leaves, number of tillers, number of rhizomes, and turmeric rhizome yield compared with the control (Table 4). PM + Mg significantly increased growth and yield parameters except plant height compared to PM alone. Using the two-year average, $\mathrm{PM}+\mathrm{Mg}$ increased turmeric yield by $7.8 \%$ compared with PM alone. NPK $+\mathrm{Mg}$ significantly increased growth and yield of turmeric compared to the other treatments. On average, NPK $+\mathrm{Mg}$ increased rhizome yield of turmeric by $13.6 \%$ and $10.6 \%$ compared with $\mathrm{PM}+\mathrm{Mg}$ and NPK fertilizer alone, respectively. Similarly, Mg fertilizer alone increased the yield of turmeric by $10.8 \%$ compared with the control.

3.4. Response of Turmeric Mineral and Vitamins. All amendments significantly increased $(\mathrm{p}<0.05)$ turmeric rhizomes' $\mathrm{Na}, \mathrm{K}, \mathrm{Mg}, \mathrm{Ca}, \mathrm{Fe}$, and vitamins $\mathrm{C}$ and $\mathrm{A}$ compared with the control (Table 5). With the exception of $\mathrm{K}, \mathrm{PM}+\mathrm{Mg}$ significantly increased the mineral and vitamins in turmeric rhizomes compared with the other treatments. The values of $\mathrm{Fe}, \mathrm{Ca}$, and vitamin $\mathrm{C}$ for $\mathrm{PM}+\mathrm{Mg}$ were not significantly different from that of PM alone. NPK $+\mathrm{Mg}$ had higher value of $\mathrm{K}$ compared with $\mathrm{PM}+\mathrm{Mg}$. Except for $\mathrm{K}$, PM alone increased mineral and vitamins contents of turmeric rhizome compared with NPK fertilizer alone. Except for Mg, the Mg fertilizer alone had the least effect on mineral and vitamin content of turmeric compared to all other soil amendments applied.

\section{Discussion}

Results show that $\mathrm{PM}$ alone or in combination with $\mathrm{Mg}$ fertilizer $(\mathrm{PM}+\mathrm{Mg})$ increased both the $\mathrm{pH}$ and nutrient contents of the soil. The increase in soil nutrient content with $\mathrm{PM}$ was adduced to the fact that PM is a natural and effective source of plant nutrients [21,22]. This was also consistent with the analysis recorded for PM in this experiment showing that it contains these nutrients. PM also has liming effect [23]. $\mathrm{NPK}$ alone or in combination with $\mathrm{Mg}$ fertilizer $(\mathrm{NPK}+\mathrm{Mg}$ ) increased $\mathrm{N}, \mathrm{P}, \mathrm{K}$, and $\mathrm{Mg}$ contents of the soil.

$\mathrm{Mg}$ fertilizer alone increased $\mathrm{N}, \mathrm{P}, \mathrm{K}, \mathrm{Ca}$, and $\mathrm{Mg}$ contents of the soil significantly compared with the control. Soil analysis prior to the start of the experiment showed that the soil was deficient of $\mathrm{Mg}$. It has commonly been reported that sandy soils are frequently deficient of Mg [24], whereas fine textured soils (clay) generally contain adequate $\mathrm{Mg}$ as $\mathrm{Mg}$ is located in clay minerals and associated with cation exchange sites on clay surfaces. The increase in $\mathrm{N}$ concentration as a result of $\mathrm{Mg}$ fertilizer could be adduced to the fact that $\mathrm{Mg}$ seems to enhance $\mathrm{N}$ availability in soil and utilization by crops [25-27]. 
TABLE 2: Chemical analysis of poultry manure and chemical fertilizers used.

\begin{tabular}{lcc}
\hline Property & Poultry manure & NPK fertilizer \\
\hline $\mathrm{pH}($ water) & 6.67 & \\
Ash (\%) & 13.1 & \\
Organic C (\%) & 21.1 & 15 \\
Total N (\%) & 2.8 & \\
$\mathrm{C}: \mathrm{N}$ ratio & 7.35 & 15 \\
$\mathrm{P}(\%)$ & 1.41 & 15 \\
$\mathrm{~K}(\%)$ & 1.86 & \\
$\mathrm{Ca}(\%)$ & 0.81 & \\
$\mathrm{Mg}(\%)$ & 0.59 & \\
$\mathrm{Na}(\%)$ & 0.29 & \\
$\mathrm{Cu}(\%)$ & 0.35 & \\
$\mathrm{Mn}(\%)$ & 0.24 & \\
$\mathrm{~S}(\%)$ & 0.28 & \\
$\mathrm{Zn}(\%)$ & 0.25 & \\
\hline
\end{tabular}

Compared with other treatments, NPK + Mg significantly increased soil $\mathrm{N}, \mathrm{P}$, and $\mathrm{K}$ concentrations. This was due to high quantities of these elements in NPK fertilizer compared with poultry manure. $\mathrm{PM}+\mathrm{Mg}$ increased $\mathrm{OM}, \mathrm{Ca}, \mathrm{Mg}$, and $\mathrm{pH}$ compared with NPK fertilizer because the organic materials in PM decomposed to release $\mathrm{OM}$ and other nutrients. The ability of PM to increase $\mathrm{pH}$ could be due to the presence of base cations contained in the PM [28]. It had been reported that such cations are released upon microbial decarboxylation [29].

PM increased the growth and yield of turmeric in this study compared with the control. This was due to high concentration of nutrients in PM and also due to its low C: $\mathrm{N}$ ratio [7.35], which, in turn, would increase OM decomposition and subsequent nutrient release. [10] also reported that turmeric responded well to PM application. The increase in the growth and yield of turmeric as a result of the application of NPK fertilizer was due to the fact that the soil of the experimental site lacked essential nutrients responsible for growth and yield of turmeric [30]. [9] reported response of turmeric to NPK 15-15-15. This response was due to nitrogen in NPK fertilizer promoting leaf growth and required to form proteins and chlorophyll, while $\mathrm{P}$ contributes to root development, energy transfer reactions, and cell division and multiplication and $\mathrm{K}$ contributes to stem development, cell division, formation and translocation of carbohydrates, and mainly tuber/rhizome development in roots.

Results show significant or higher yields of turmeric where $\mathrm{Mg}$ fertilizer is added with PM $(\mathrm{PM}+\mathrm{Mg})$ or NPK $(\mathrm{NPK}+\mathrm{Mg})$ compared with PM or NPK alone. These results were expected because $\mathrm{Mg}$ is known to be a constituent of chlorophyll accounting for about $2.7 \%$ of the chlorophyll molecule. It is also a cofactor, an enzyme activator in reaction associated with ATP formation, phosphorylation reaction, and subsequent transfer of phosphate [7]. Therefore, $\mathrm{Mg}$ is involved in simultaneously controlling processes responsible for photosynthesis, assimilate production, and partitioning among plant parts [31]. $\mathrm{Mg}$ supply was also reported to enhance $\mathrm{N}$ uptake by plants $[32,33]$. Mg application has also been reported to increase the translocation of assimilate from source to sink organs which increases root growth $[5,34]$. The increase in root growth as a result of $\mathrm{Mg}$ fertilizer application may aid in the absorption of $\mathrm{N}$ and other nutrients in the soil, thereby enhancing growth and rhizome yield of turmeric. [12] reported an increase in rhizome yield of turmeric as a result of $\mathrm{MgSO}_{4}$ when applied as a foliar spray.

NPK increased growth and rhizome yield of turmeric compared with PM. Although PM had been reported to increase growth and yield of crops [21], the elemental quantity of N, P, and K in NPK fertilizer was higher than that of PM, which may explain the yield differences between NPK and PM. Turmeric is a high nutrient demanding crop; in this regard, [35] obtained good yields of turmeric rhizomes with the combination of 375,175 , and $237.5 \mathrm{~kg}$ of N, $\mathrm{P}_{2} \mathrm{O}_{5}$, and $\mathrm{K}_{2} \mathrm{O}$, respectively.

$\mathrm{NPK}+\mathrm{Mg}$ increased yield of turmeric compared with NPK alone, likely due to the complementary effect of NPK and $\mathrm{MgO}$ fertilizers. [36] reported that secondary nutrients also play important roles in producing higher yields of turmeric. Also, [37] recommended high application rates of secondary nutrients, i.e., $\mathrm{Mg}$ at $22 \mathrm{~kg} \mathrm{ha}^{-1}$ and Sulphur at $44 \mathrm{~kg} \mathrm{ha}^{-1}$, and a recommended dose of NPK fertilizer for improved yield of turmeric.

Mg fertilizer (applied alone or in combination with PM or NPK fertilizer) increased mineral and vitamin contents of turmeric rhizomes. This can be related to improved soil chemical properties associated with $\mathrm{Mg}$ treatments which, in turn, may have resulted in increased metabolic activity. $\mathrm{Mg}$ fertilizer also increased $\mathrm{N}$ absorbed by the turmeric plants and resulting in an increase in the number of leaves and photosynthetic activity and enhancing physiological processes leading to higher assimilate production which also resulted in an increase in mineral composition in the rhizomes.

In this experiment, $\mathrm{PM}$ alone or applied with $\mathrm{Mg}$ fertilizer $(\mathrm{PM}+\mathrm{Mg})$ increased $\mathrm{Na}, \mathrm{K}, \mathrm{Mg}, \mathrm{Ca}, \mathrm{Fe}$, and vitamins contents of turmeric rhizome compared with NPK fertilizer alone or in combination with $\mathrm{Mg}$ fertilizer $(\mathrm{NPK}+\mathrm{Mg})$. This might be due to differences in the chemical composition 


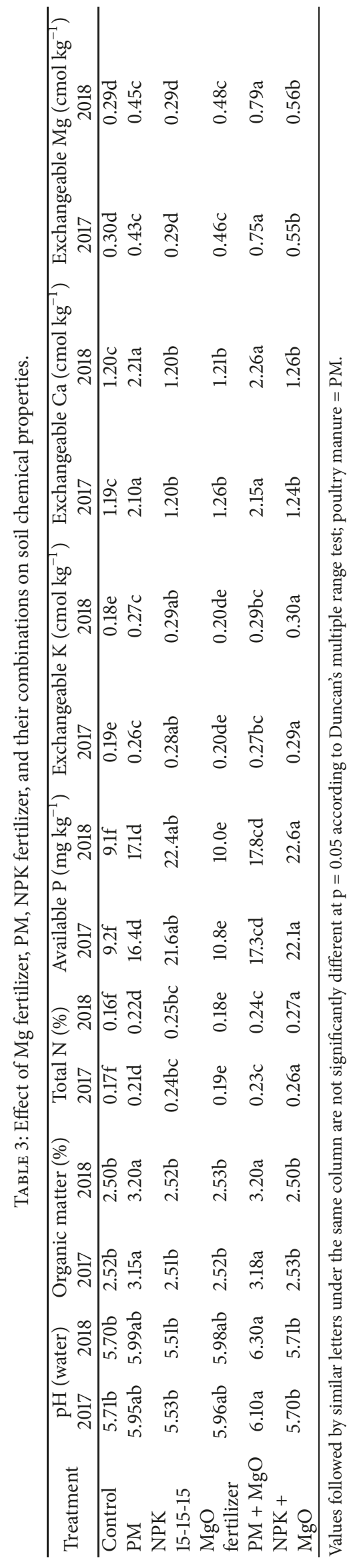


TABLE 4: Effect of Mg fertilizer, PM, NPK fertilizer, and their combinations on performance of turmeric.

\begin{tabular}{|c|c|c|c|c|c|c|c|c|c|c|}
\hline \multirow{2}{*}{ Treatment } & \multicolumn{2}{|c|}{ Plant height $(\mathrm{cm})$} & \multicolumn{2}{|c|}{ Number of leaves } & \multicolumn{2}{|c|}{ Number of tillers } & \multicolumn{2}{|c|}{ Number of rhizomes } & \multicolumn{2}{|c|}{ Fresh rhizome weight $\left(\mathrm{t} \mathrm{ha}^{-1}\right)$} \\
\hline & 2017 & 2018 & 2017 & 2018 & 2017 & 2018 & 2017 & 2018 & 2017 & 2018 \\
\hline Control & $51.2 \mathrm{~d}$ & $50.3 d$ & $9.3 \mathrm{e}$ & 9.1e & $3.1 \mathrm{e}$ & $3.1 \mathrm{e}$ & $9.1 \mathrm{e}$ & $9.0 \mathrm{e}$ & $19.4 \mathrm{e}$ & $19.2 \mathrm{e}$ \\
\hline PM & $63.8 b$ & $64.1 \mathrm{~b}$ & $12.1 \mathrm{c}$ & $12.7 \mathrm{c}$ & $4.4 c$ & $4.6 \mathrm{c}$ & $14.1 \mathrm{c}$ & $14.3 \mathrm{c}$ & $25.2 c$ & $25.8 \mathrm{c}$ \\
\hline $\begin{array}{l}\text { NPK } \\
15-15-15\end{array}$ & $69.7 \mathrm{ab}$ & $69.2 \mathrm{ab}$ & $13.6 \mathrm{~b}$ & $13.9 \mathrm{~b}$ & $4.8 \mathrm{~b}$ & $4.7 \mathrm{~b}$ & $15.2 \mathrm{~b}$ & $15.1 \mathrm{~b}$ & $28.4 \mathrm{~b}$ & $28.1 \mathrm{~b}$ \\
\hline $\begin{array}{l}\mathrm{MgO} \\
\text { fertilizer }\end{array}$ & $54.7 \mathrm{~cd}$ & $54.9 \mathrm{c}$ & $10.8 \mathrm{~d}$ & $10.8 \mathrm{~d}$ & 3.3de & 3.1de & $10.3 \mathrm{~d}$ & $10.1 \mathrm{~d}$ & $21.7 \mathrm{~d}$ & 21.1d \\
\hline $\mathrm{PM}+\mathrm{MgO}$ & $67.4 \mathrm{ab}$ & $68.9 \mathrm{ab}$ & 13.1ab & 14.1ab & $4.9 \mathrm{~b}$ & $5.1 \mathrm{~b}$ & $15.7 \mathrm{~b}$ & $16.0 \mathrm{~b}$ & $27.1 \mathrm{~b}$ & $27.9 b$ \\
\hline $\begin{array}{l}\mathrm{NPK}+ \\
\mathrm{MgO}\end{array}$ & $73.2 \mathrm{a}$ & 73.9a & $14.3 \mathrm{a}$ & $14.8 \mathrm{a}$ & $5.3 \mathrm{a}$ & $5.6 \mathrm{a}$ & $16.4 \mathrm{a}$ & $16.7 \mathrm{a}$ & $31.6 \mathrm{a}$ & $30.9 \mathrm{a}$ \\
\hline
\end{tabular}

Values followed by similar letters under the same column are not significantly different at $\mathrm{p}=0.05$ according to Duncan's multiple range test; poultry manure $=$ PM.

TABLE 5: Effect of Mg fertilizer, PM, NPK fertilizer, and their combinations on mineral and vitamin contents of turmeric rhizome (means of 2017 \& 2018 pooled).

\begin{tabular}{|c|c|c|c|c|c|c|c|}
\hline & $\mathrm{Na}(\%)$ & $\mathrm{K}(\%)$ & $\operatorname{Mg}(\%)$ & $\mathrm{Ca}(\%)$ & $\mathrm{Fe}(\%)$ & Vitamin C (\%) & Vitamin A (\%) \\
\hline Control & $142.6 \mathrm{f}$ & $101.7 \mathrm{f}$ & $221.2 \mathrm{e}$ & $81.6 \mathrm{e}$ & $7.2 f$ & $1.2 \mathrm{f}$ & $4.5 \mathrm{f}$ \\
\hline Poultry manure (PM) & $256.3 c$ & $125.8 \mathrm{~d}$ & $323.3 c$ & $136.6 \mathrm{ab}$ & $17.2 \mathrm{ab}$ & $2.5 \mathrm{ab}$ & $13.6 \mathrm{~b}$ \\
\hline NPK 15-15-15 & $201.7 \mathrm{~d}$ & $130.1 \mathrm{ab}$ & $285.7 \mathrm{~d}$ & $92.4 \mathrm{~d}$ & $14.7 \mathrm{~d}$ & $1.8 \mathrm{~d}$ & $9.5 \mathrm{~d}$ \\
\hline MgO fertilizer & $192.6 \mathrm{e}$ & $110.5 \mathrm{e}$ & $368.3 b$ & $100.1 \mathrm{~cd}$ & $12.7 \mathrm{e}$ & $1.5 \mathrm{e}$ & $7.3 e$ \\
\hline $\mathrm{PM}+\mathrm{MgO}$ & $527.8 \mathrm{a}$ & $129.3 \mathrm{~cd}$ & 402.1a & $140.4 \mathrm{a}$ & 18.1a & $2.8 \mathrm{a}$ & $15.6 \mathrm{a}$ \\
\hline $\mathrm{NPK}+\mathrm{MgO}$ & $321.6 \mathrm{~b}$ & $137.7 \mathrm{a}$ & $286.3 \mathrm{~d}$ & $96.7 \mathrm{~cd}$ & $15.6 \mathrm{~cd}$ & $2.0 \mathrm{c}$ & $10.6 \mathrm{~cd}$ \\
\hline
\end{tabular}

Values followed by similar letters under the same column are not significantly different at $\mathrm{p}=0.05$ according to Duncan's multiple range test.

of PM compared to NPK fertilizer and its positive effect on soil ecology and plant metabolism [38]. NPK fertilizer contains only $\mathrm{N}, \mathrm{P}$, and $\mathrm{K}$, whereas $\mathrm{PM}$ contains both macro- and micronutrients. It therefore seems reasonable that the amount and type of mineral nutrients present in the soil will dictate the quantity and quality of nutrients absorbed by the plant. For example, plants grown under organic agricultural conditions are reported to have higher micronutrient contents than conventionally grown plants [39]. Furthermore, because some chemical reactions in cells involve micronutrients, either directly or indirectly [40] could explain why PM exhibited higher vitamin C content compared with NPK fertilizer [38]. The increased mineral and vitamin contents of turmeric rhizomes as a result of application of $\mathrm{NPK}+\mathrm{Mg}$ and $\mathrm{PM}+\mathrm{Mg}$ compared with NPK or PM alone can be adduced to increase soil chemical properties as a result of the $\mathrm{Mg}$ fertilizer addition which led to greater metabolic activities and hence higher minerals and vitamins in the $\mathrm{NPK}+\mathrm{Mg}$ and $\mathrm{PM}+\mathrm{Mg}$ plots compared with their sole forms.

\section{Conclusion}

This study shows that PM, NPK, and Mg fertilizers alone or combinations increased soil chemical properties, growth, yield, and mineral and vitamin contents of turmeric rhizomes compared with the control. For this experiment, NPK + $\mathrm{Mg}$ increased growth and yield of turmeric compared with other treatments. The NPK $+\mathrm{Mg}$ treatment increased the yield of turmeric compared with NPK alone, likely due to the complementary effect of NPK and Mg fertilizers. The $\mathrm{PM}+\mathrm{Mg}$ fertilizer treatment significantly improved mineral and vitamins contents compared with the other treatments. Therefore, for those that desire turmeric rhizomes for their nutritive value, $\mathrm{PM}+\mathrm{Mg}$ is recommended. For those that want quantity, $\mathrm{NPK}+\mathrm{Mg}$ is recommended.

\section{Data Availability}

The data used to support the findings of this study are included within the article.

\section{Conflicts of Interest}

There are no conflicts of interest among authors.

\section{References}

[1] M. Z. U. Kamal and M. N. Yousuf, "Effect of organic manures on growth, rhizome yield and quality attributes of turmeric (Curcuma longa L.)," The Agriculturists, vol. 10, no. 1, pp. 16-22, 2012.

[2] P. V. Balashanmugam and N. Chezhiyan, "Effect of differential application of nitrogen on growth and yield of turmeric," Madras Agricultural Journal, vol. 73, no. 6, pp. 439-442, 1986.

[3] W. B. Tomori, O. A. Obijole, and A. F. Aiyesanmi, "Evaluation of nutrient status of cropped and degraded soils - research note," Nigerian Journal of Soil Science, vol. 16, pp. 178-180, 2006.

[4] V. K. Sanghamithre and M. V. Menon, "Effect of S, Ca and Mg on fresh rhizome yield of turmeric (Curcuma longa L.)," Journal of Tropical Agriculture, vol. 52, no. 2, pp. 158-161, 2014. 
[5] I. Cakmak and E. A. Kirkby, "Role of magnesium in carbon partitioning and alleviating photooxidative damage," Physiologia Plantarum, vol. 133, no. 4, pp. 692-704, 2008.

[6] I. Cakmak and A. M. Yazici, "Magnesium-a forgotten element in crop production," Better Crops, vol. 94, pp. 23-25, 2010.

[7] O. O. Agbede, Understanding Soil and Plant Nutrition, Petra Digital Press, Abuja, Nigeria, 2009.

[8] M. R. Broadley and P. J. White, "Eats roots and leaves. Can edible horticultural crops address dietary calcium, magnesium and potassium deficiencies?" Proceedings of the Nutrition Society, vol. 69, no. 4, pp. 601-612, 2010.

[9] T. O. Ojikpong, "Effect of Planting Dates and NPK (15:15:15) Fertilizer on the growth an yield of turmeric (Curcuma longa Linn)," International Journal of Agriculture \& Environmental Science, vol. 5, no. 4, pp. 42-46, 2018.

[10] L. U. Ihenacho, H. A. Okorie, I. E. Chriso, and C. A. PeterOnoh, "Effect of poultry manure on the growth and yield of turmeric (curcuma longaL) in Nigeria," Journal of Agriculture and Veterinary Science, vol. 8, no. 1, pp. 34-38, 2015.

[11] A. K. Sadanandan, K. V. Peter, and S. Hamza, "Soil nutrient and water management for sustainable spices production," in Proceedings of the National Seminar on Water and Nutrient Management for Sustainable Production and Quality of Spices. ISS, IISR, 1998, pp. 12-20, Calicut, India, October 1997.

[12] R. Chandra, A. R. Desai, and S. Govind, "Effect of foliar spray of magnesium and planting materials on growth and yield of turmeric," Journal of Hill Research, vol. 10, no. 1, pp. 1-4, 1997.

[13] G. W. Gee and D. Or, "Particle-size analysis," in Methods of soil analysis, Part 4. Physical methods. Book Series No. 5, J. H. Dane and G. C. Topp, Eds., pp. 255-293, Soil Science Society of America, Madison, WI, USA, 2002.

[14] D. W. Nelson and L. E. Sommers, "Total carbon, organic carbon and organic matter," in Methods of Soil Analysis. Part 3, D. L. Sparks, Ed., vol. No. 5 of SSSA Book Series No. 5, pp. 961-1010, ASA and SSSA, Madison, WI, USA, 2nd edition, 1996.

[15] J. M. Bremner, "Nitrogen-total," in Methods of Soil Analysis. Part 3. Chemical Methods, D. L. Sparks, Ed., Book Series No. 5, pp. 1085-1121, ASA and Soil Science Society of America, Madison, WI, USA, 2nd edition, 1996.

[16] K. Frank, D. Beegle, and J. Denning, "Phosphorus," in Recommended Chemical Soil Test Procedures for the North Central Region, North Central Regional Research Publication No. 221 (revised), J. R. Brown, Ed., pp. 21-26, Missouri Agric. Exp. Station, Columbia, MO, USA, 1998.

[17] W. H. Hendershot, H. M. Lalande, and M. Duquette, "Ion exchange and exchangeable cations," in Soil Sampling and Methods of Analysis, M. R. Carter and E. G. Gregorich, Eds., pp. 173-178, Canadian Society of Soil Science, CRC Press, Boca Raton, FL, USA, 2nd edition, 2008.

[18] AOAC, Official Methods of Analysis of the Association of Official Analytical Chemists International, AOAC International, Gaithersburg, MD, USA, 17th edition, 2003.

[19] A. K. Sadanandan, K. V. Peter, and S. Hamza, "Soil nutrient and water management for sustainable spices production," in Proceedings of the National seminar on water and nutrient management for sustainable production and quality of spices. ISS, IISR 1998, pp. 12-20, Calicut, India, October 1997.

[20] M. R. Carter and E. G. Gregorich, Soil Sampling and Methods of Analysis, Canadian Society of Soil Science, CRC Press, Boca Raton, FL, USA, 2nd edition, 2007.
[21] A. O. Adekiya, T. M. Agbede, and S. O. Ojeniyi, "The effect of three years of tillage and poultry manure application on soil and plant nutrient composition, growth and yield of cocoyam," Experimental Agriculture, vol. 52, no. 3, pp. 466-476, 2016.

[22] T. M. Agbede and S. O. Ojeniyi, “Tillage and poultry manure effects on soil physical properties, nutrients status, growth, dry matter and grain yield of sorghum," Journal of Agricultural Science and Technology, vol. 4, no. 3, pp. 45-59, 2010.

[23] J. N. Odedina, S. O. Ojeniyi, and S. A. Odedina, "Comparative effect of animal manures on soil nutrients status and performance of cassava," Nigerian Journal of Soil Science, vol. 21, no. 1, pp. 58-63, 2011.

[24] H. F. Mayland and S. R. Wilkinson, "Soil factors affecting magnesium availability in plant-animal systems: a review," Journal of Animal Science, vol. 67, no. 12, pp. 3437-3444, 1989.

[25] F. Gastal and G. Lemaire, "N uptake and distribution in crops: an agronomical and ecophysiological perspective," Journal of Experimental Botany, vol. 53, no. 370, pp. 789-799, 2002.

[26] O. Shaul, "Magnesium transport and function in plants: the tip of the iceberg," BioMetals, vol. 15, no. 3, pp. 309-323, 2002.

[27] G. Rubio, J. Zhu, and J. P. Lynch, "A critical test of the two prevailing theories of plant response to nutrient availability," American Journal of Botany, vol. 90, no. 1, pp. 143-152, 2003.

[28] A. O. Adekiya, T. M. Agbede, C. M. Aboyeji, O. Dunsin, and V. T. Simeon, "Biochar and poultry manure effects on soil properties and radish (Raphanus sativus L.) yield," Biological Agriculture \& Horticulture, vol. 35, no. 1, pp. 33-45, 2018.

[29] L. Nätscher and U. Schwertmann, "Proton buffering in organic horizons of acid forest soils," Geoderma, vol. 48, no. 1-2, pp. 93106, 1991.

[30] P. E. Ogbonna and N. J. Nweze, "Evaluation of growth and yield responses of cocoyam (Colocasia esculenta) cultivars to rates of NPK 15:15:15 fertilizer," African Journal of Agricultural Research, vol. 7, no. 49, pp. 6553-6561, 2012.

[31] M. Senbayram, A. Gransee, V. Wahle, and H. Thiel, "Role of magnesium fertilizers in agriculture: plantsoil continuum," Crop \& Pasture Science, vol. 66, pp. 1219-1229, 2015.

[32] W. Grzebisz, P. Barlóg, and R. Lehrke, "Effect of the interaction between the method of magnesium application and amount of nitrogen fertilizer application on sugar recovery and technical quality of sugarbeet (Beta vulgaris L.)," Zuckerindustrie, vol. 126, no. 12, pp. 956-960, 2001.

[33] W. Grzebisz, "Crop response to magnesium fertilization as affected by nitrogen supply," Plant and Soil, vol. 368, no. 1-2, pp. 23-39, 2013.

[34] S. A. Casson and K. Lindsey, "Genes and signalling in root development," New Phytologist, vol. 158, no. 1, pp. 11-38, 2003.

[35] M. R. Rao, K. R. C. Reddy, and M. Subbarayudu, "Promising turmeric types of Andhra Pradesh," Indian Spices, vol. 12, pp. 2-5, 1975.

[36] M. Velmurugan, N. Chezhiyan, M. Jawaharlal, V. Davamani, and V. Vijayaraghavan, "Effect of inorganic nutrients on turmeric-a review," Agricultural Reviews, vol. 29, no. 3, pp. 220-225, 2008.

[37] P. Bose, D. Sanyal, and K. Majumdar, "Balancing sulfur and magnesium nutrition for turmeric and carrot grown on red lateritic soil," Better Crops, vol. 92, no. 1, pp. 23-25, 2008.

[38] S. A. Hassan, S. Mijin, U. K. Yusoff, P. Ding, and P. E. Wahab, "Nitrate, ascorbic acid, mineral and antioxidant activities of cosmos caudatus in response to organic and mineral-based fertilizer rates," Molecules, vol. 17, no. 7, pp. 7843-7853, 2012. 
[39] D. Hunter, M. Foster, J. O. Mcarthur, R. Ojha, P. Petocz, and S. Samman, "Evaluation of the micronutrient composition of plant foods produced by organic and conventional agricultural methods," Critical Reviews in Food Science and Nutrition, vol. 51, no. 6, pp. 571-582, 2011.

[40] L. R. Howard, N. Pandjaitan, T. Morelock, and M. I. Gil, "Antioxidant capacity and phenolic content of spinach as affected by genetics and growing season," Journal of Agricultural and Food Chemistry, vol. 50, no. 21, pp. 5891-5896, 2002. 


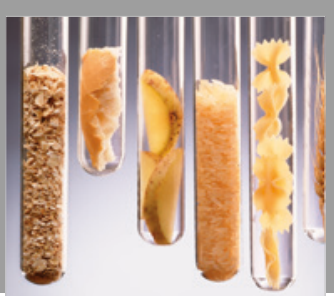

International Journal of Food Science

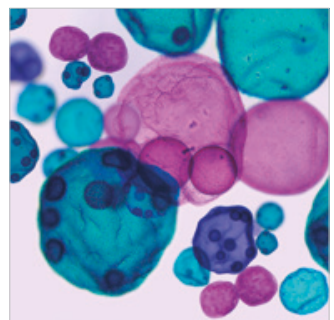

International Journal of Microbiology
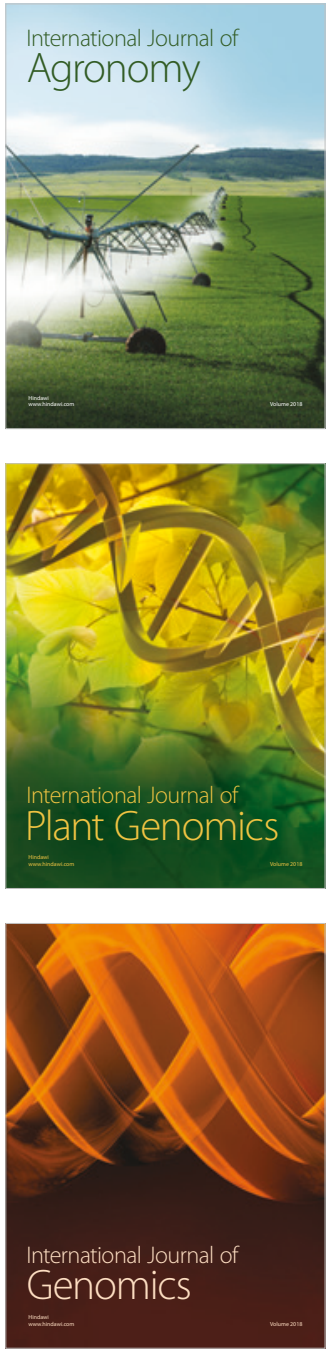

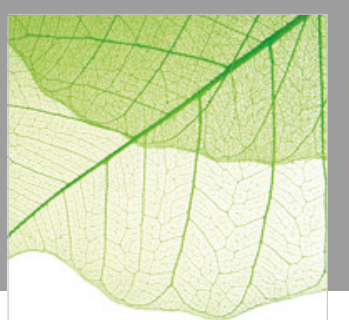

Journal of Botany


Submit your manuscripts at

www.hindawi.com




Scientifica

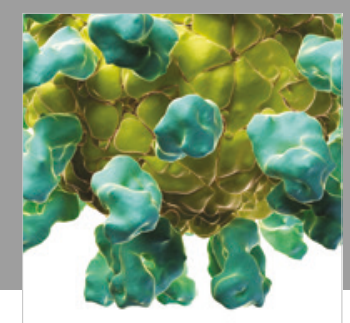

Veterinary Medicine International

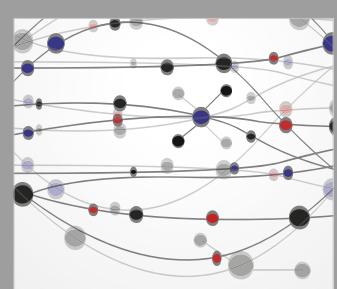

The Scientific World Journal
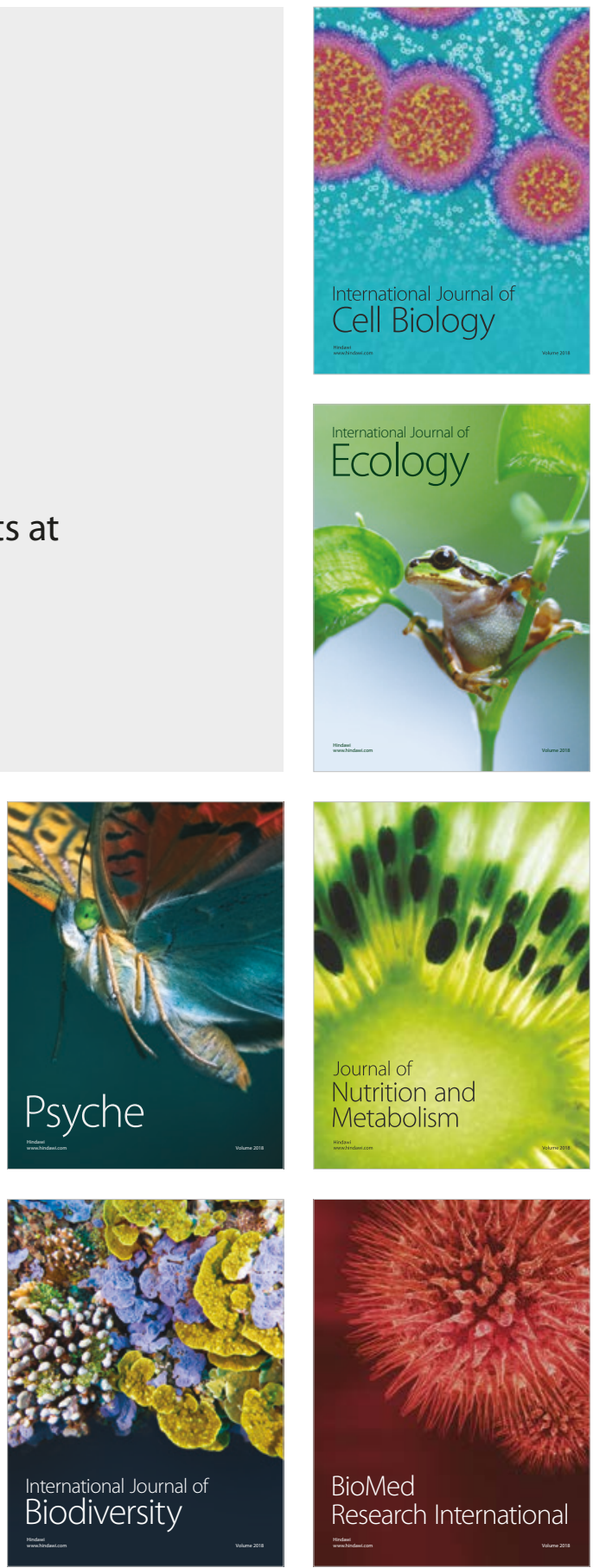